\title{
The Science Policy Script, Revised
}

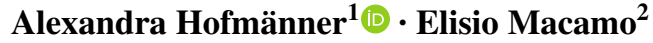

Accepted: 25 November 2020 / Published online: 10 February 2021

(C) The Author(s) 2021

\begin{abstract}
The paper considers the notion of Science Policy from a postcolonial perspective. It examines the theoretical implications of the recent trend to include emerging and developing countries in international Science Policies by way of the case study of Switzerland. This country's new international science policy instruments and measures have challenged the classical distinction between international scientific cooperation and development cooperation, with consequences on standards and evaluation criteria. The analysis reveals that the underlying assumptions of the concept of Science Policy perpetuate traditional asymmetries in the global political economy of science. The paper suggests that the present legacy of Science Policy institutions and practices needs to be transformed to reflect an increasingly diverse spectrum of scientific purposes and traditions. It offers a revised set of foundational assumptions on Science Policy and, more broadly, proposes a fresh point of entry for the field of Science \& Technology Studies (STS) to contribute to the Science Policy discourse.
\end{abstract}

Keywords Postcolonial Science Policy · International Scientific Cooperation • Development Cooperation · Antithetical Signifiers

Alexandra Hofmänner

alexandra.hofmaenner@unibas.ch

Elisio Macamo

elisio.macamo@unibas.ch

1 Science \& Technology Studies, Department of Social Sciences, University of Basel, Basel, Switzerland

2 Department of Social Sciences, University of Basel, Basel, Switzerland 


\section{Introduction}

\section{STS and Science Policy}

The term Science Policy is ubiquitous: it brands government strategies and reports; entitles public agencies, permanent committees, offices of international organisations and initiatives; and labels university degree courses. It is also flexible: it is implied in expressions such as 'Science and Technology Policy', 'Innovation Policy', and 'Research \& Development (R\&D) Policy'. The term Science Policy is in addition to this powerful: it is brought into play to justify public expenditure for scientific research and to enable funding agencies and steering commissions to preside over the evaluation of knowledge claims. Mostly, the analytical toolkit to study, interpret and speak about Science Policy across these settings is drawn from the fields of Science Policy Studies or Research and Innovation (R\&I) Studies. ${ }^{1,2}$

The intellectual roots of the study of Science Policy, however, may be traced back to the newly emerging field of Science and Technology Studies (STS) in the early 1970s (Spiegel-Rösing and de Solla Price 1977). Academic research on Science Policy was advocated by early pioneers of STS as a key rationale to establish this interdisciplinary academic field. The academic discourse on Science Policy, however, quickly branched out to form a separate field of academic study in its own right (Salomon 1977). Many of the founding scholars of the field of Science Policy Studies had been involved in the early Science Policy initiatives of the OECD of the 1960s and applied approaches from political science or evolutionary economics (Godin 2009; Martin 2012).

To be sure, renowned STS scholars have time and again engaged the subject of Science Policy. ${ }^{3}$ STS scholars have made repeated calls to address the 'segregation' of 'science studies and science policy' throughout its history (Hackett et al. 2007: 4). The most recent STS Handbook confirms that the study of Science Policy has not found its way back onto the mainstream intellectual agenda of the field of STS (Felt et al. 2017). ${ }^{4}$ Much of the academic work of the STS community, however, relates directly to Science Policy issues, institutions, actors and discourses, and the far-reaching explanatory power of the notion of Science Policy may be expected to persist in the future. Recent developments in international Science Policy afford a window of opportunity for STS to step up its contribution to this discourse.

\footnotetext{
1 This is not to claim that STS journals do not publish papers relating to Science Policy, but to point out that Science Policy discourse in practice relies on other academic sources for policy guidance.

2 This paper will use the term "Science Policy Studies" to encompass these various fields of academic research concerned with Science Policy matters that have arisen since the 1970s.

3 See, for example, Rip (1994), Jasanoff (1990, 2005), Gibbons et al. (1994), Elzinga and Jamison (1995), Elzinga (2004, 2012), Weingart (1999, 2001), Nowotny (2007), Nowotny, Scott and Gibbons (2001), Fuller and Collier (2004), Webster (2007), Wynne (2007), Sismondo (2008), Garforth and Stöckelová (2012).

4 The 'epistemic landscape' of the new Handbook of STS contains no chapter, cross-cutting issue or theme dedicated to the notion of Science Policy (Felt et al. 2017).
} 


\section{New International Science Policies in Western Europe}

Over the past decade, new international Science Policy initiatives in Western Europe to expand international scientific cooperation and science diplomacy to emerging and developing countries have seen the light of day. Their rationale rests on the notion of a new global political economy of knowledge, with shifting sites of scientific power and conditions for research. The leading role of Western Europe, North America, and Japan faces a challenge from a growing 'multi-polar' system in which emerging economies assume new roles. In response to these dynamics, new international Science Policies have been formulated (Hofmänner 2018).

In this vein, the European Union (EU) has taken steps to enhance international scientific cooperation and science diplomacy with emerging and developing countries (European Commission 2008, 2012a, b; European Parliament 2015). ${ }^{5}$ The EU framework programme Horizon 2020 considered international cooperation with industrialised countries and emerging economies and developing countries a key priority to ensure competitiveness (European Commission 2018). Its calls were in principle "Open to the World" and invited participation of international partners from all over the world, with the EU offering at least partial funding. ${ }^{6}$ New policy instruments were developed to implement this strategic expansion, including strategy documents, legislation, advisory committees, and funding programmes. ${ }^{7}$ In parallel, several EU member states and associated countries, too, expanded the geographic range of their international Science Policies. ${ }^{8}$ This historically unique move breaks with a long-standing Western European tradition of Science Policy largely focused within the boundaries of Western Europe.

The effectiveness of these new international Science Policies in Western Europe has not yet been assessed. However, there is evidence that the envisaged expansion of scientific cooperation to emerging and developing countries devised to respond to a new global political economy of science has encountered unanticipated challenges and has led to inconsistencies at the Science Policy level. Third-country participation in Horizon 2020 has declined despite the EU's new "Open to the World" strategy, and concerns have been voiced that some features of the framework programme may in fact hinder such co-operation (European Commission 2016). A recent case study on new international science policies in Switzerland suggests that the traditional conceptual framework of the notion of Science Policy offers limited explanatory power for these new international policy circumstances (Hofmänner 2018).

\footnotetext{
5 In 2012, the EU published a strategy for EU international cooperation in research and innovation (European Commission 2012a, b).

${ }^{6}$ http://ec.europa.eu/research/participants/docs/h2020-funding-guide/cross-cutting-issues/internationalcooperation_en.htm (accessed 20 July 2018).

7 For example, the European Research Area and Innovation Committee of the EU instituted a Strategic Forum for International S\&T Cooperation (SFIC) in 2012, to advise the EU on international cooperation in the context of Horizon 2020 and the preparation of the 9th EU Framework Programme for Research and Innovation.

${ }^{8}$ Germany, Austria, the UK, Ireland and Norway are cases in point.
} 
This paper submits that these new challenges remain poorly understood because the traditional notion of Science Policy is ill-suited to capture the inconsistencies of the new international science policies in the changing global political economy of science. It argues that the new semantics of geographical expansion used to describe the movement of international Science Policy to emerging and developing countries call for postcolonial perspectives. These perspectives refashion the theoretical underpinnings of the notion of Science Policy to give admission to new discourses on the kinds of problems at stake. More broadly, the paper aims to illustrate the benefits of the postcolonial STS perspective for the Science Policy discourse.

\section{Research Approach and Methodology}

This paper probes the conceptual and analytical scope of the traditional Science Policy script from a postcolonial perspective. It aims to re-align the terms of the debate on Science Policy to better reflect current developments, and to identify obstacles to the shift in discourse. The paper assumes that the new international science policy instruments and measures challenge the foundational assumptions of Science Policy, and that postcolonial approaches offer analytical tools to conceptually refurbish this notion to better reflect contemporary circumstances. Postcolonial analysis of Science Policy underscores recurrent but hitherto unheeded calls to summon postcolonial insights from STS' peripheries and to accommodate them in its mainstream programme. ${ }^{9}$

\section{The Postcolonial Lens on Science Policy}

The history of Science Policy is usually portrayed as an idea born in OECD countries of the early 1960s, from where it spread across the globe. In this script, the dissemination process did not change the internal characteristics of Science Policy, which are of generic and universal nature and for this reason develop detached from particular contextual circumstances. This script follows suit with the Whig interpretation of the history of ideas which projects a trajectory from their origins in the Global North to the Global South.

Postcolonial scholarship has put forward alternative analytical perspectives on the history of ideas. ${ }^{10}$ It has drawn attention to the ways in which Western European and North American concepts were co-constituted in relation to the histories of the rest of the world. The notions of 'entangled histories' (Conrad and Randeria 2002) and' connected sociologies' (Bhambra 2014) capture this alliance and underscore

\footnotetext{
${ }^{9}$ Postcolonial science studies scholars have introduced to the field of STS critical conversations on the colonial legacy of science and its epistemological consequences (e.g. Anderson 2002; McNeil 2005; Prasad 2008; Anderson and Adams 2008; Seth 2009; Harding 2008, 2011; Hofmänner 2020).

10 See Said (1977), Mudimbe (1988), Spivak (1988), Trouillot (1991, 2002, 2003), Pratt (1992), Hall (1992), Bhabha (1994), Escobar (1994, 1999), Appadurai (1996), Mitchell (2000a, b), Chakrabarty (2002, 2008), Knauft (2002), Randeria (1999a, b, 2002), Bhambra (2007, 2011, 2014), Macamo (2016), Connell and Dados (2014), Connell et al. (2018), and others.
} 
the consequences of its absence in the historical analysis of concepts that claim universal validity. Rather than expose these concepts as biased, postcolonial critique seeks to replenish their explanatory power to change the terms of the debate.

To date, the notion of Science Policy has not yet been subjected to the postcolonial analytical gaze. Therefore, in its current academic scripture, the historiography of this idea follows in the tracks of the centre-periphery storyline tradition: Science Policy writes world history as a universal idea born in Western Europe and North America but at the same time, it silences its historical specificity.

The postcolonial perspective asks for the ways in which the concept of Science Policy was co-constituted in relation to the histories of the Rest of the world, and what the implications of this entanglement are on its analytical and interpretive scope. Postcolonial thought offers no standard methodological prescriptions for pursuing these questions. This paper will follow the postcolonial analytical lens presented by the notions of 'antithetical signifiers' or pairs of binary opposition, such as modern/traditional, developed/developing, civilized/savage etc. (Conrad and Randeria 2002; Trouillot 2002; Hall 1992; and others). Antithetical signifiers function as gatekeepers to the universal scope of Western European ideas; they cast the ideal, utopian idea against its absence, elsewhere (Trouillot 2002). They draw attention to the conditions and forces that have constituted these ideas and shed light on their implicit universal language.

The dominant historical approach to Science Policy traces its trajectory of expansion beyond Western Europe and North America. If we follow the postcolonial line of argument, the idea of Science Policy can be studied by searching for and decoding the binary signifiers framing this trajectory. The paper hypothesises that the terms 'international scientific cooperation' and 'development cooperation' have performed as antithetical signifiers in the historical script on Science Policy. It claims that the empirical study of new international science policies in Switzerland provides an excellent empirical foil to investigate this hypothesis.

\section{The Swiss Case}

Switzerland has recently introduced new international Science Policies to expand international scientific cooperation and science diplomacy to emerging and developing countries. For most of the country's history, its international Science Policies had focused primarily on the geographical bounds of Western Europe (SSTC 2009; Fleury and Zala 2012; Schlegel 2014). Shortly after the turn of the century, the Swiss Federal Council issued a federal directive to expand international Science Policies to emerging and developing countries (Hofmänner 2018). The decision broke with the long-standing Swiss tradition of international Science Policies to secure the country's access to European research initiatives. ${ }^{11}$

\footnotetext{
11 The early strategic emphasis, in a first phase, to participate in early European research projects from 1952 to 1973, was extended to European research programmes from 1973 to 1990, after which Switzerland gained third-party status in the emerging European Research Framework Programmes (FPs) of the EU. These decades of scientific diplomacy led to Switzerland's full association in the FPs of the EU in 2004. One year later, the strategic focus of Swiss international scientific cooperation and science diplomacy on Europe was expanded to emerging and developing countries (Hofmänner 2018).
} 
New international Science Policy instruments and measures have been introduced since, to implement the envisaged expansion of international Science Policy. These include Switzerland's first 'International Strategy for Education, Research and Innovation' of 2010 (SER 2010), revised legislation on research and innovation, new national research programmes, new tools for science diplomacy, new bilateral and international agreements, and new international committees, delegations and commissions (Hofmänner 2018).

However, these new international science policy instruments and measures have encountered systemic difficulties and have disclosed policy inconsistencies. In particular, they have struggled to address two of the mayor challenges of international research cooperation between the global North and the global South: the uneven balance of power and skewed benefits caused by different research conditions and the simultaneous evaluation of the dual standards of scientific excellence and developmental relevance. ${ }^{12}$ In fact, in a recent turnaround these instruments and measures have retreated their efforts to address these problems. For example, in recent times the Swiss National Science Foundation (SNSF) and the Swiss Agency for Development Cooperation (SDC) have introduced separate research promotion programmes $^{13}$ to replace their previous joint funding of large joint national research programmes. ${ }^{14}$ Importantly, the official evaluation criteria of the SNSF's programmes only commend but do not oblige projects to meet the requirement of developmental relevance.

Switzerland qualifies for postcolonial analysis although the country has no legacy of colonial territories and has not figured prominently in debates on colonialism and postcolonialism. New studies have unearthed some of the country's colonial and postcolonial entanglements. They have challenged the historical narrative of Switzerland's 'outsider' status to colonialism, a narrative shared by several other smaller European countries, such as Austria and the Nordic countries (Purtschert and Fischer-Tiné 2015). Their close involvement with European colonial history has been exposed by applying concepts such as 'colonial complicity' (Keskinen et al. 2009), 'colonial exceptionalism' (Loftsdottir and Jensen 2012) and 'colonialism without colonies' (Osterhammel 2010; Lüthi et al. 2016) to the spheres of business, trade,

\footnotetext{
12 Successful research partnerships have been shown to depend on their ability to integrate these two different standards. The many challenges involved in this endeavour are described in the Guide for Transboundary Research Partnerships of the Swiss Commission for Research Partnerships with Developing Countries (KFPE) (https://naturalsciences.ch/organisations/kfpe/11_principles_7_questions, accessed 9 April 2020).

13 The SNSF offers several research funding options for international scientific cooperation, including the bilateral research programmes with Brazil, Chile, China, India, Japan, Korea, Russia, and South Africa and the new Swiss Programme for International Research by Scientific Investigation Teams (SPIRIT). The SDC has recently launched the programme TRANSFORM which requires the involvement of stakeholders outside of academia to promote sustainable development goals.

14 These three generations of large North-South research promotion programmes include a module on development in the Swiss Priority Programme Environment (1992-1999); the National Centre of Competences in Research North South (2001-2013); and the Swiss Programme for Research on Global Issues for Development (2012-2022).
} 
industry, art, religion, science, and others (Purtschert and Fischer-Tiné 2015; Harries 2007; Randeria 2002; Meier 2015).

Switzerland's colonial legacy also lies concealed in its historical relationship with Europe because the country has been implicated in many direct and indirect ways by European colonialism and transnational colonial systems (Purtschert et al. 2016). While Switzerland formally claims political neutrality and national sovereignty at the outskirts of the European Union, de facto its history is inseparable from Europe's process of integration, which is strongly correlated with European colonialism (Hansen and Jonsson 2017). For these reasons, Switzerland qualifies as empirical case study for applying the postcolonial lens to its new international science policies.

\section{Definitions and Structure of the Paper}

The paper analyses the empirical case study of Switzerland to probe the Science Policy script from a postcolonial perspective. For empirical purposes, 'international science policies' are referred to in this paper as an umbrella phrase to designate governing actions and responsibilities that concern matters relating to science beyond the boundaries of the nation state. Governance occurs by way of rules, norms and official decisions (legislation, statutory orders, decrees by government agencies or public administration), particularly through the allocation of financial resources (Hofmänner 2018). The expression 'international scientific cooperation' is employed to denote all forms of research collaboration that cross the boundaries of the nation state. The term 'development cooperation' is used to label cross-boundary research collaboration that emphasises development priorities and objectives. Lastly, the general extended definition of 'science diplomacy' is adopted from the Royal Society and the AAAS. ${ }^{15}$

The paper first outlines the standard history of the origins and development of the notion of Science Policy and formulates the foundational assumptions of this traditional Science Policy script. Then, the foundational assumptions of the idea of Science Policy are tested against inconsistencies encountered in the new instruments and tools of Switzerland's new international Science Policies to expand international scientific cooperation to emerging and developing countries. The analysis of international scientific cooperation and development cooperation probes their role as a pair of antithetical signifiers in sustaining the traditional Science Policy script. The next chapter attempts to refashion the theoretical and discursive terrain of the notion of Science Policy by revising its set of assumptions. Finally, conclusions are drawn from the analysis to contribute to current debates and academic analyses of Science Policy in STS.

\footnotetext{
15 The Royal Society and the American Association for the Advancement of Science (AAAS) defined 'Science diplomacy' as 'a fluid concept that can usefully be applied to the role of science, technology and innovation in three dimensions of policy: informing foreign policy objectives with scientific advice (science in diplomacy); facilitating international science cooperation (diplomacy for science); and using science cooperation to improve international relations between countries (science for diplomacy).' (The Royal Society 2010: v-vi).
} 


\section{The Traditional Science Policy Script: Three Foundational Assumptions}

'That is, the ad hoc Group tried to define and explore that new area of governmental concern that is coming to be known by the shorthand term "science policy".'

(OECD Report on the First Ministerial Meeting on Science in Paris in October 1963)

Some 60 years ago, the term Science Policy was not yet in circulation. Its historical origins are undisputed in the academic literature: Science Policy originated in the circles of the Organisation for Economic Co-operation and Development (OECD) in the early 1960s, driven by historical circumstances in post-Second World War Europe. ${ }^{16}$ Founded by European countries in 1948 as the Organisation for European Economic Cooperation (OEEC) ${ }^{17}$ to administer the Marshall Plan for reconstruction in Europe, the organisation was reconstituted as the OECD in 1961 to focus on the joint promotion of economic growth and trade, with an expanded membership of twenty countries that included Canada and the US (Mesthene 1965: 27).

The OECD is considered to have occupied a key position in codifying the concept of Science Policy within only a few years (Henriques and Larédo 2013). The organisation quickly set up international and national advisory committees and bodies, organised international conferences and meetings, and issued reports on Science Policy (Salomon 1977; Elzinga and Jamison 1995; Guston 1996). Scholars from the field of Science Policy Studies sometimes also recognize the role of UNESCO in the genealogy of Science Policy but generally acknowledge Western Europe and North America as sites of origin from which the idea then spread to other places.

Science Policy is typically portrayed as an area of public policy at the level of the nation state. International Science Policy, in this routine, designates the geographic extension of this area of public policy beyond the boundaries of the nation state. Up until the early new millennium, this extension mainly referred to Western European countries, North America and Japan. While some exceptions may be found to this rule, international Science Policy in Western Europe and North America certainly did not include postcolonial settings - collaboration in these settings fell under the auspices of international development policy and development cooperation.

\footnotetext{
16 See Spaey (1971), Salomon (1973), Finnemore (1993), Elzinga and Jamison (1995), Guston (1996, 2000), Van der Meulen (1998), Porter and Webb (2008), Godin (2009), Elzinga (2012), Martin (2012), Henriques and Larédo (2013). Although most historical accounts of Science Policy set the origins of this notion in the early 1960s, a preparatory phase is usually identified following the Second World War. In several accounts, this preparatory phase, in turn, is viewed 'as the product of various initiatives taken between World Wars I and II' (Ronayne 1984; Martin 2012). A number of reports issued under the auspices of the OEEC/OECD, NATO and UNESCO are typically referenced as sources to make the case for the beginning of the era of Science Policy (Wilgress 1960; NATO 1960; Auger 1961; OECD 1962a, b; Piganiol et al. 1963). One particular event - the First Ministerial Meeting on Science, which convened under the auspices of the newly established OECD in October 1963-is usually named as the birthplace of Science Policy.

17 The OEEC's founding member countries included Austria, Belgium, Denmark, France, Greece, Iceland, Ireland, Italy, Luxembourg, Netherlands, Norway, Portugal, Sweden, Switzerland, Turkey, and the United Kingdom.
} 
There is similar scholarly agreement on Science Policy designating an area of public policy: The literature on the history of Science Policy typically recounts the emergence and development of an autonomous domain of national public policy that led to the establishment of permanent structures in public administration in member and non-member states (Jang 2000). ${ }^{18}$ Prior to its advent in the 1960s, science was considered a cross-cutting policy affair, an issue of concern to several policy domains such as foreign policy or military policy, rather than a policy domain in its own right. The history of Science Policy, therefore, is usually written as the evolution of a domain of public policy under the sovereignty and jurisdiction of the nation state. Several experts involved in this project were at the same time key figures in establishing the academic field of Science Policy Studies (Salomon 1973, 1977).

By virtue of this definition, the notion of Science Policy is conceptually tied to the political and geographic boundaries of the nation state. By implication, international Science Policy designates its strategic extension beyond these boundaries; however, the nation state remains the underlying unit of analysis for theoretical and empirical investigations of Science Policy.

The OECD documents on the origins of Science Policy show that international considerations were a key rationale for the establishment of this domain of public policy. Science Policy was promoted as a solution to a number of specific problems the OECD member countries faced at the time. Among these was the geopolitical situation of increased economic, scientific and technological competition in the Cold War, in which the relative importance of Europe in the world economy was seen to be declining (King 1965). Science and technology came to be viewed as a key economic factor that would help the European economy catch up to the US and the USSR. ${ }^{19}$ International cooperation among Western European countries was seen as an essential building block to secure a strong place in these competitive circumstances. However, international scientific and technological initiatives, organisations and programmes had been increasing since the Second World War, and Western European countries were increasingly faced with investment decisions beyond their national boundaries and budgets. The OECD's answer to this second problem was for members to develop national Science Policies (OECD 1965; Salomon 1965, 1977; Freeman 1967). These national Science Policies would then inform decision making on international cooperation: 'The root idea here is that effective international Science Policy must rest on strong national Science Policies' (Augier 1961 in OECD 1965: 177-8).

National Science Policies, in turn, required statistical data on their effectiveness within the science and technology landscape (OECD 1962b; Freeman et al. 1965; Freeman 1969; Godin 2008, 2009). Furthermore, the newly established direct link between national economic growth and scientific and technological capacity required statistical data on the scientific capacity of a nation. Both sets of statistics required categories and definitions in order to collect data. The new domain of

\footnotetext{
18 See Spaey (1971), Salomon (1973), Finnemore (1993), Elzinga and Jamison (1995), Guston (1996), Porter and Webb (2008), Godin (2009), Martin (2012), Henriques and Larédo (2013).

19 Wilgress (1960), Auger (1961), NATO (1960), OECD (1962a, 1965), Spaey (1971).
} 
public policy was promoted as the solution to tackle these problems. Early categories and statistics of the OECD focused specifically on the natural sciences, with plans to design parallel indicators for the social sciences and humanities later on (OECD 1962b; Freeman et al. 1965). However, the original indicators came to be adopted as standards for scientific peer review criteria and processes more generally (Elzinga and Jamison 1995; Godin 2008, 2009).

This Science Policy script may be characterised by three foundational assumptions:

First assumption: Science Policy is a domain of public policy; its development is recorded by the history of this domain of public policy in nation states.

Second assumption: Science Policy falls under the political sovereignty of national governments; its business is attended to by institutions, structures and processes at the interface of national science and national politics.

Third assumption: International Science Policy is an extension of national Science Policy; national and international Science Policies are intrinsically complementary.

The interplay of national and international science was a key issue motivating a new separate domain of public policy. Because of this vital link, it is important to examine the implications of the recent expansion of international Science Policy instruments and measures to emerging and developing countries on the very concept of Science Policy. For this reason, the following section probes the foundational assumptions of Science Policy in the context of the new generation of international Science Policies in Switzerland.

\section{A Postcolonial Perspective on New International Science Policies in Switzerland}

\section{Inconsistencies in the New International Science Policies}

A recent study of the new era of international Science Policies of Switzerland has disclosed several inconsistencies in the implementation of its new instruments and measures (Hofmänner 2018). First, the new Science Policy initiatives have discredited the efficacy of the categories 'international scientific cooperation' and 'development cooperation' to capture the variety of types of international research collaboration with emerging and developing countries. They have compounded the territorial jurisdictions of two domains of public policy and their agencies: Science Policy and Development Policy. This has caused confusion on the distribution of authority and responsibility for international Science Policy, which has also affected the design of scientific evaluation procedures and quality criteria for international scientific cooperation with non-European countries.

Second, the new international Science Policy initiatives have involved decisions that challenge existing institutions, structures and processes at the interface 
of national science and national politics, which is occupied by multiple actors and complex legal issues. Third, the new international Science Policies are no simple spatial continuation of previous international Science Policies and diplomacy with Western European countries but bring with them a set of new legal, administrative and research challenges. Fourth, the Swiss study has refuted the common postulate that national and international Science Policies are intrinsically complementary.

The following section explores these inconsistencies to test the foundational assumptions of the concept of Science Policy.

\section{The Foundational Assumptions of Science Policy, Revisited}

"It is thus that the concept of "science policy" has appeared in all developed countries. It is truly a too recent a notion for agreement to be possible on its exact meaning'.

(Théo Lefèvre, Introductory Speech to the First Ministerial Meeting on Science, Paris, 1963)

First assumption: Science Policy is a domain of public policy; its history records the development of this domain of public policy in national governments.

The recent expansion of international Science Policies to emerging and developing countries in Switzerland has stirred up long-standing jurisdictional territories of two federal departments, officially concerned with science and foreign affairs respectively. ${ }^{20} \mathrm{New}$ initiatives in international scientific cooperation and science diplomacy have required a redistribution of tasks and responsibilities of these two domains of public policy and their subordinate agencies, but critical challenges for Science Policy governance and public administration have remained unresolved.

In particular, the classical distinction between international scientific cooperation and development cooperation, which previously had settled the distribution of power and administrative duties for scientific matters amongst these two departments has been put to the test. This dual system of classification has sustained segregated structures and procedures in federal policy and administration. Substantial activities in international scientific cooperation since the 1960s have not been running under the rubric of 'Science Policy'. Instead, international scientific cooperation with most of the world's regions was administered under the label of 'development cooperation' and under the rubric of 'development policy'.

The Swiss case refutes the assumption that Science Policy designates a single domain of public policy; therefore, Science Policy cannot be portrayed by

\footnotetext{
${ }^{20}$ In legal terms, responsibility for international Science Policies in Switzerland rests with the Swiss State Secretariat for Education, Research and Innovation (SERI) at the Federal Department of Economic Affairs, Education and Research (EAER). The expansion of international scientific cooperation to emerging and developing countries, however, exposed that in practice this agency had only attended to a small selection of Western European and industrialised countries. Cooperative activities with other countries had previously been managed under the banner of 'development cooperation' under the auspices of the Swiss Development Corporation (SDC) at the Federal Department of Foreign Affairs (FDFA).
} 
recording the historical development of a single domain of public policy in national governments.

Second assumption: Science Policy falls under the political sovereignty of national governments; its business is attended to by institutions, structures and processes at the interface of national science and national politics.

Over the past decade, the number and diversity of players with stakes in international scientific cooperation and science diplomacy in Switzerland have multiplied. Switzerland's new focus on emerging and developing countries has introduced new kinds of institutional partners, legal conditions, political alliances and economic stakeholders to Science Policy affairs. Collaboration with partners beyond the liberal democracies of Western Europe involves a new diversity of research traditions and institutional histories. The advent of new stakeholders, institutions, traditions and issues presents new situations for international scientific cooperation that challenge the political sovereignty of the Swiss national government. Furthermore, its traditional Science Policy institutions, structures and procedures were devised to mediate between science and politics at the national level, and not across the entire scale from global to local.

Science Policy was brought into being to anchor national governments' state sovereignty on scientific matters. To achieve this goal, institutions and mechanisms had to be established to mediate between the national communities of science and politics. ${ }^{21}$ At the international scale, they were designed to serve international scientific cooperation and science diplomacy with the liberal-democratic nation states of Western Europe but not with countries beyond these boundaries. As the previous section has shown, they were not constructed to mediate between science and politics at the interface of Switzerland and countries outside of Western Europe, because research cooperation with the rest of the world was administered under the banner of development policy.

The new international Science Policies of Switzerland defy the premise that Science Policy implements a natural political sovereignty of national governments. Instead, they demonstrate that Science Policy is involved in the continuous process of contesting political sovereignty for science - not just within national governments, but across a range of international, institutional and individual scales.

Third assumption: International Science Policy is an extension of national Science Policy; national and international Science Policies are intrinsically complementary.

The new international Science Policy initiatives and measures that have arisen in Switzerland over the past decade presupposed a natural fit between national and international Science Policy objectives and instruments. ${ }^{22}$ Under closer scrutiny,

\footnotetext{
${ }^{21}$ In Switzerland, these structures were developed over the course of the past fifty years, and examples include the Swiss Science Council (1965); the Science, Education and Culture Committee of the Swiss Parliament (1967); the Division for Science and Research at the Federal Department of Home Affairs (1969); the Research Article in the Swiss Constitution (1973); the Federal Office for Science and Education (1979) and the Research Act (1983).

22 Examples for this assumption are the Swiss Federal ERI-Dispatches that apply to parliament for federal funds for education, research and innovation on a four-year basis, and reports by the Swiss State Secretariat for Education, Research and Innovation (SERI) on Swiss international research cooperation.
} 
however, the picture of a natural fit quickly disintegrates. ${ }^{23}$ National and international Science Policies attend to different kinds of issues and consequently require different kinds of policy guidance and support, and implementing instruments and processes.

The Swiss case demonstrates that international Science Policies are no simple geographical extension of national Science Policies. Furthermore, the new instruments for international Science Policies in Switzerland reveal that national and international Science Policies are not intrinsically complementary; on the contrary, they are often inconsistent or even contradictory. Activities in international scientific cooperation and science diplomacy with emerging and developing countries have raised critical questions for science institutions and agencies that typically fulfil national missions. Scientific interaction across national boundaries takes place for a variety of reasons and serves various purposes, but these activities always need to navigate forces of competition and cooperation on the world map of science. International and national Science Policies are formed amid the constant tension between international scientific competition and cooperation.

\section{International Scientific Cooperation and Development Cooperation-Antithetical} Signifiers

Before the turn of the century, Swiss scientific interaction across national boundaries was considered to take place either for the benefit of development cooperation or for the sake of scientific cooperation. The category 'international scientific cooperation' was applied selectively to particular geographical regions and not to others. Its sister category 'development cooperation' was used to distinguish international research activities with the remaining geographical regions. The Swiss experience has demonstrated that research interaction across national boundaries can no longer be dispensed through these two categories. On the other hand, simply combining their objectives and standards has not proven to be a viable path forward either. Instead, the inconsistencies encountered in the implementation of the new international Science Policies suggest a need for new guiding principles, standards and research traditions.

From a postcolonial perspective, the two sister categories, international scientific cooperation and development cooperation, are conceptually interlinked and mutually dependent. They can be portrayed as a pair of binary opposition or antithetical signifiers that sustain the concept of Science Policy. Understanding the historical conditions that allowed for their co-construction is critical for replenishing the notion of Science Policy to better represent current circumstances. What rationale led to this dual classification? What criteria were applied to justify the distinction of

\footnotetext{
23 The two principal federal policy documents for national and international Science Policies respectively-the International Strategy for ERI and the Dispatch for Education, Research and Innovation (ERI)-illustrate this problem: they do not complement one another in form or in content. They serve different purposes, attend to different issues, and are issued at different intervals.
} 
two different types of research cooperation across national boundaries? How was the separation implemented, and how could it prevail for half a century?

Prior to the 1960s, most OECD governments had no administrative agencies or central budgets for science; responsibilities were distributed across various institutions (Finnemore 1993). The growing number of international and Western European scientific organisations, projects and programmes of the 1950s increasingly compelled governments to decide on how to allocate national resources to international projects and initiatives. Thus, dealing with these decisions in a coordinated manner was one of the motivating forces for instituting the new domain of public policy.

The rationale for the distinction between international scientific cooperation and development cooperation during the foundational years of Science Policy reflects the economic and geopolitical objectives of the newly established OECD in the context of the Cold War (Krige 2006). Science Policy appeared on the agenda of the OECD immediately after its reconstitution in 1961, when the Secretary-General of the OECD appointed an ad hoc Advisory Group on Science Policy 'in part to advise him on what should be the place of science in the expanded context of the revised Organisation' (Mesthene 1965: 27). Government intervention in national and international scientific affairs was rationalised by linking science to the economic development and political standing of Europe on the world map: science was to be 'applied to economic growth' to work against the 'decline in the relative importance of Europe in the World economy' (King 1965: 24). In other words, the OECD's Science Policy project formed an essential part in the implementation of this organisation's early neoliberal agenda.

The association of science with economic growth, at the time, implied very particular theories of economic growth that connected economic growth with social development ${ }^{24}$ by classifying nations into stages of development. ${ }^{25}$ The new policy domain for science inscribed these stages of development by introducing the distinction between international scientific cooperation and development cooperation, and relegating the latter to the separate domain of Development Policy.

The implementation of the classification was of great (albeit indirect) consequence to the formation of Science Policy and is symbolically expressed in two meetings that took place in 1963; the First Ministerial Meeting on Science Policy in Paris, organised under the auspices of the OECD (Mesthene 1965), and the Conference on the Application of $S \& T$ for the Benefit of the Less Developed Areas (UNCSAT), hosted by the United Nations in Geneva (United Nations 1963). The two events instantiated a pair of grand ideas: the twin conception of Science Policy and Development Policy, corroborated by neoliberal discourses on economic growth and

\footnotetext{
${ }^{24}$ Walter Rostow's classic theory of economic growth illustrates this approach: it postulated five stages of development that needed to be passed through: 'the traditional society; the preconditions for take-off; the take-off; the drive to maturity; the age of high mass consumption' (Rostow 1959).

25 George Basalla formulated this idea in his three-stage model on "The Spread of Western Science" which referred directly to W.W. Rostow's Stages of Economic Growth (1960). Basalla's model described 'the manner in which modern science was transmitted to the lands beyond Western Europe' (Basalla 1967: 620).
} 
development in Western Europe in the 1960s. These two parallel events symbolically and practically inscribed the division between international scientific cooperation and development cooperation. They illustrate that the formation of the notion of Science Policy was tied to the formation of the notion of Development Policy. Both areas of public policy, in turn, were promoted to advance the OECD's neoliberal policy agenda. Postcolonial studies have portrayed this policy agenda as a development strategy that does not simply project Northern ideology elsewhere but rather re-weaves worldwide economic and social relationships (Connell and Dados 2014: 124).

Science Policy was seen as a solution to blend economic and scientific objectives of Western European countries into a single domain of public policy. This discourse relied on an image of science that required intervention by national governments to secure their international economic competitiveness. This image, in turn, required normative standards and categories to evaluate science and international scientific cooperation and its counterpart, development cooperation. These standards and categories were endorsed in new statistical approaches to measure science that emerged in the early 1960s. In this way, the twin conceptions of international scientific cooperation and development cooperation encoded the economic system of classifying nations by economic stage of development into the notion of Science Policy. This code instituted a segregated view of the world of science: removing all countries outside Western Europe and North America from the map of scientific nations relegated them to a position from which they were forever having to catch up with the scientific expertise of the liberal-democratic nation states of the OECD. These codes and standards informed the emerging images of good practice for Science Policy. In this way, the notion of Science Policy played an important role in re-weaving worldwide economic and social relationships according to the neoliberal world order and market agenda (Connell and Dados 2014: 124).

The traditional image of scientific practice crossing national borders either for the benefit of development cooperation or for the sake of scientific cooperation has become unsuitable for contemporary Science Policy environments. Likewise, the association of these two categories with different scientific standards, purposes, types of research practices (basic and applied research) and evaluation criteria (scientific and developmental) has lost its validity in practice. New images of scientific practice crossing national borders will require renewed discussions and agreements on new categories and redressing the objectives of international scientific cooperation, which had been settled in favour of economic and political standpoints in the early days of Science Policy. Science Policy's epistemological complicity with neoliberalism (Connell and Dados 2014) and with specific cultural images of knowledge and science (Elkana 1981) is imprinted in these objectives.

\section{New Images, New Assumptions}

'It is not that scientists in underdeveloped countries are technically untrained or technically incompetent; it is rather that, being a part of their national culture, they will themselves lack or will not be able to impose or recreate in their 
society and culture, so alien to science, those fundamental orientations (if they have them) which are necessary for really productive research. It is under such conditions that political leaders will have to promulgate policies and execute decisions on science'. (Stevan Dedijer 1963: 70)

The analysis has shown that the effective separation of international scientific cooperation and development cooperation in actual fact has served to engender not only the new domain of Science Policy, but also its sister domain of Development Policy. Thus, taking this historical perspective, the origin tale of Science Policy is one of dialectical relationship; neither domain of public policy could have been instituted and realised any success without the other. As such, a new Science Policy script would need to attend to the discursive co-formation of both domains of policy.

These considerations bring into focus the powerful, long-standing influence of the concept of Science Policy on the global political economy of science. The two ideas of Science Policy and Development Policy validated and endorsed at a global scale a powerful set of rules and standards for science and knowledge over the last 60 years. These rules and standards reach far beyond the scope of Science Policy as a domain of public policy — as it is cast in current historiography_and enacted a vision of separate scientific development in the West and the non-West. This segregated vision was endorsed by a clear separation of competencies for knowledge production related to 'international scientific cooperation' and 'development cooperation.' Separate standards were developed and applied to validate and authorise research in Western and non-Western countries. These were implemented in separate public policy agencies, programmes and standard evaluation procedures and criteria.

Standard approaches to policy initiatives see them as part of normal politics, i.e. ordinary policy work within nation states. A postcolonial perspective mounts an essential challenge to this view in that it contests the "national" character of national politics when it takes place in the countries of the world which have shaped world history to their own advantage. Science policy, in this sense, is not just about the emergence of a new area of policy. It is world-making in fundamental respects. Much in line with the idea of heterogeneous engineering (Law 1987) that looks into how technology constructs the societies hosting it, science policy does not only define what science is in a given country, but also what it should be in those countries bereft of economic and political clout in the neoliberal world order.

What the script of Science Policy has produced in terms of world-making is a powerful new distinction between basic and applied research where the former plays second fiddle to the latter and, in the context of developing countries, the latter becomes constitutive of what counts as science. In other words, international science cooperation as a result of the emergence of Science Policy as a field of public policy reduces science and scholarship in the developing world to applied science. Applied research assumes no further conceptual work and for this reason, the reduction of science to applied research protects Northern conceptual dominance from critical scrutiny while furthering the power of its institutions to mould the world in 
its own image. ${ }^{26}$ In this way, economic and political asymmetries between the global North and the global South are reproduced through practices of Science Policy.

The new 'expansion' of international science cooperation and science diplomacy to emerging and developing countries in Western European countries over the past decade has invalidated the opposing semantics of international scientific cooperation and development cooperation. It has unveiled the discursive character of the notion of Science Policy, whereby the formation of Science Policy was inseparably intertwined with the emergence of the idea of Development Policy. The discursive perspective replaces Whig history of Science Policy's origins in Europe with postcolonial historiography, which emphasises a genealogy of global entanglement. The new Science Policy script therefore involves a shift in unit of analysis from Science Policy as a domain of public policy in liberal-democratic nation states to its discursive formation. This shift in analytical perspective offers a new framework to review the current Science Policy script and provides the theoretical framework to formulate new foundational assumptions: Instead of casting Science Policy as a domain of public policy and writing its history as the development of this domain in national government ...

First assumption, revisited: ... Science Policy is framed as a discourse that promotes particular images of science and of scientific practice crossing national borders. Its conceptual history is recorded by the history of pairs of antithetical signifiers that categorise and authenticate normative standards for science (revised first assumption).

Instead of falling under the political sovereignty of national governments, where the business of Science Policy is attended to by the institutions, structures and processes at the interface of national science and national politics ...

Second assumption, revisited: ... Science policy results from a continuous dialectical process of contesting political sovereignty for science. This process takes place within and outside of national governments and spans interand transnational, national, regional and institutional scales (revised second assumption).

Instead of viewing international Science Policy as an extension of national Science Policy, where national and international Science Policies are intrinsically complementary ...

Third assumption, revisited: ... International and national Science Policies are formed in constant dialectical tension between competition and cooperation, and between the universal and the specific (revised third assumption).

The standard notion of Science Policy rests not only on foundational assumptions but also on the standard categories for scientific practice crossing national borders. Both aspects need to be considered to renew the conceptual scope and conceptual

${ }^{26}$ See Elisio Macamo's discussion of “scientific power" in Ramutsindela et al. (2016), in Macamo (2018) and in Ouédraogo, Diawara and Macamo (2018). 
outfit of Science Policy. Replacing the old assumptions on Science Policy with new ones may provide a new way of framing the issues at stake and new starting points for analysis of current challenges and opportunities. Moreover, it is equally necessary to revise the standards and norms for scientific practice across national boundaries because these gatekeepers for science ultimately determine which problems will be addressed and by what means.

\section{Conclusion: A New Science Policy Script}

The term 'Science Policy' has captured the contemporary imagination. It is broadly employed to imply possible courses of public action that hold the promise of prospective social and economic benefits to 'the knowledge society'. The term is applied to designate both national and international scientific affairs of countries. An entire academic field has been dedicated to its study; since the early 1960s, Science Policy Studies scholars have continued to put forward theories and concepts to describe, analyse and compare Science Policies of countries across the globe.

Recently, new international Science Policies have been implemented in Western European countries to address the new conditions of a changing global political economy of science. They aim at expanding international scientific cooperation and science diplomacy to emerging and developing countries. In Switzerland, new Science Policy initiatives have been launched and new Science Policy tools and measures have been implemented to pursue this goal.

Up until the early twenty-first century, the term 'international scientific cooperation' in Switzerland specifically designated scientific cooperation with Western European and industrialised countries. Research cooperation with countries outside of this region was labelled 'development cooperation'. International scientific cooperation and development cooperation were evaluated in different terms, according to their core mission achieve academic excellence or developmental relevance respectively. The recent expansion in Western Europe of international scientific cooperation and science diplomacy to emerging and developing countries has challenged the validity of these segregated categories and their respective scientific standards.

The Swiss case study demonstrates that the classical notion of Science Policy is unsuitable to capture and make sense of the many inconsistencies in its new international Science Policies. Several foundational assumptions of the concept of Science Policy do not apply to these Swiss circumstances. Since foundational assumptions provide the framework for any historical scripture on a concept, the case study argues for revising these assumptions to develop a new Science Policy script that better reflects current circumstances.

The particular historical imprint of the notion of Science Policy is significant. The classical historical narrative situates the origins of Science Policy in the OECD of the early 1960s. Historically, the line separating international scientific cooperation from development cooperation stems not from scientific criteria but from the economic and political classification of nations that was commonly used in the early 1960s. Drawing this line impelled statistical categories and standards for science to sustain the hierarchical classification: an exclusive, superior type of research 
cooperation was held in reserve for Western countries (basic and applied scientific research) while a secondary, inferior type of research cooperation was attributed to non-Western countries (applied research for development).

Standard histories of Science Policy have followed the image of a segregated global inheritance of knowledge that can be mapped onto countries. In this way, the genesis of Science Policy instantiated dual standards for science at the global scale, which in turn reinforced global geopolitical asymmetries. These dual standards were validated by the alleged complementarity of national and international Science Policies. The current Science Policy script, therefore, is founded upon the division between international scientific cooperation and development cooperation as a pair of binary, or antithetical, signifiers. Writing the history of Science Policy as a single domain of public policy eclipses these mechanisms and their institutional and procedural legacy.

The continual perpetuation of this particular notion of Science Policy and its assumptions at a global scale have far-reaching consequences. A segregated system of science is propagated, where dual standards for evaluating knowledge are enshrined in the legacy of international organisations, in national public administration and in categories and evaluation criteria for research funding. This system endorses existing asymmetries in the global political economy of science.

This paper suggests replacing the standard historiographic approach to Science Policy as a single domain of public policy, with a discursive approach that traces the dynamics of international scientific cooperation and development cooperation as a pair of antithetical signifiers that categorise and authenticate normative standards for science. It further proposes to reconsider the normative standards and criteria used to appraise and evaluate international scientific cooperation, with particular focus on their impact on the disparities in the current global political economy of science. In particular, the new international Science Policy initiatives with emerging and developing countries need to be subjected to empirical examination that considers the entire spectrum of different purposes, objectives, tools, prospective outputs and institutional traditions of scientific practices carried out across national borders. This is likely to entail setting up new institutional structures, processes and agencies, and therefore calls for changes in the existing institutional landscape of Science Policy at national and international levels.

The Swiss case indicates that it is tempting to assume a moderate strategy in the face of the complexity of new challenges, and to assimilate the new initiatives into existing institutional and procedural Science Policy structures. This path would endorse current conceptions of Science Policy, but the solution may prove to be shortlived, since it is unlikely to address the magnitude of challenges involved in the current transformation of the global political economy of science and the changes in research practice of the digital age. The economic mission of science was the central rationale for the new field of Science Policy in the late 1960s; this view persists to this day and has overshadowed other purposes of scientific practice and international scientific cooperation. Scientific research on the grand global challenges of our times, such as migration, climate change, health, digitalisation, agriculture, urbanisation and many others, cannot be correlated with economic paybacks to nation states. It has long been argued that the particular economic imprint of Science Policy—and its vestige 
of statistical categories that is rooted in the natural sciences-has favoured certain knowledge disciplines over others. This analysis suggests that the new generation of international Science Policies in Western Europe provide a unique opportunity to realign the concept of Science Policy to contemporary challenges.

The changing global political economy of science has not simply reshuffled the terms and stakes for Science Policy. Instead, it has brought forward inconsistencies that challenge the very concept of Science Policy. Cosmetic changes to Science Policy institutions and instruments at the national level are unlikely to succeed in addressing these challenges. The specific profile of Science Policy, its foundational assumptions and images of science matter because they provide the rationale for selecting and attending to critical problems, and because they entitle certain actors in the global political economy of science, and debar others.

Throughout STS's history, there have been recurrent calls to bridge the divide between STS and other fields of study on Science Policy. The field of STS has yet to carve out the terrain for its conceptual contribution to the study of Science Policy as it relates to current affairs. The paper suggests that the postcolonial perspective provides essential analytical tools to support this endeavour. The postcolonial rationale, however, cannot simply be added on to the peripheries of the body of scholarship of STS but requires shifting perspectives of its mainstream intellectual agenda.

Acknowledgements This article deliberates the theoretical implications for the field of STS of research undertaken for the Swiss Science Council (SSC) by the first author in the exploratory study New International S\&T Policies: Key Issues and Questions in Switzerland (2018).

Funding Open Access funding provided by Universität Basel (Universitätsbibliothek Basel).

Open Access This article is licensed under a Creative Commons Attribution 4.0 International License, which permits use, sharing, adaptation, distribution and reproduction in any medium or format, as long as you give appropriate credit to the original author(s) and the source, provide a link to the Creative Commons licence, and indicate if changes were made. The images or other third party material in this article are included in the article's Creative Commons licence, unless indicated otherwise in a credit line to the material. If material is not included in the article's Creative Commons licence and your intended use is not permitted by statutory regulation or exceeds the permitted use, you will need to obtain permission directly from the copyright holder. To view a copy of this licence, visit http://creativecommons.org/licenses/by/4.0/.

\section{References}

Anderson, Warwick, and Vincanne Adams. 2008. Pramoedya's Chickens: Postcolonial Studies of Technoscience. In Handbook of Science and Technology Studies, 3rd ed, eds. Edward J. Hackett, Olga Amsterdamska, Michael Lynch, and Judy Wajcman, 181-204. Cambridge: MIT Press.

Anderson, Warwick. 2002. Introduction: Postcolonial Technoscience. Social Studies of Science 32(5/6): 643-658.

Appadurai, Arjun. 1996. Modernity at Large: Cultural Dimensions of Globalization. Minneapolis: University of Minnesota Press.

Auger, Pierre. 1961. Current Trends in Scientific Research. Paris: United Nations and UNESCO.

Basalla, George. 1967. The Spread of Western Science. A three-stage model describes the introduction of modern science into any non-European nation. Science 156(5 May): 611-622.

Bhabha, Homi K. 1994. The Location of Culture. London UK/New York: Routledge.

Bhambra, Gurminder K. 2007. Rethinking Modernity: Postcolonialism and the Sociological Imagination. New York: Palgrave Macmillan. 
Bhambra, Gurminder K. 2011. Historical Sociology, Modernity, and Postcolonial Critique. American Historical Review 116(3): 653-662.

Bhambra, Gurminder K. 2014. Connected Sociologies. London: Bloomsbury.

Chakrabarty, Dipesh. 2002. Habitations of Modernity. Chicago: University of Chicago Press.

Chakrabarty, Dipesh. 2008 [2000]. Provincializing Europe: Postcolonial Thought and Historical Difference. Princeton: Princeton University Press.

Connell, Raewyn, and Nour Dados. 2014. Where in the World Does Neoliberalism Come From? Theory and Society 43(2): 117-38.

Conrad, Sebastian, and Shalini Randeria. 2002. Jenseits des Eurozentrismus: Postkoloniale Perspektiven in den Geschichts- und Kulturwissenschaften. Frankfurt a.M.: Campus Verlag.

Dedijer, Stevan. 1963. Underdeveloped science in underdeveloped countries. Minerva 2(1): 61-81.

Elkana, Yehuda. 1981. A Programmatic Attempt at an Anthropology of Knowledge. In Sciences and Cultures, eds. Everett Mendelsohn and Yehuda Elkana, 1-76. Dordrecht: Reidel.

Elzinga, Aant, and Andrew Jamison. 1995. Changing Policy Agendas in Science and Technology. In Handbook of Science and Technology Studies, eds. Sheila Jasanoff, Gerald Markle, James Petersen, and Trevor Pinch, 572-597. Thousand Oaks, CA: Sage.

Elzinga, Aant. 2004. The New Production of Reductionism in Models Relating to Research Policy. In The Science-Industry Nexus: History, Policy, Implications, eds. Karl Grandin, Nina Wormbs, and Sven Widmalm, 277-304. Sagamore Beach, Mass: Science History Publications.

Elzinga, Aant. 2012. Features of the current science policy regime: Viewed in historical perspective. Science and Public Policy 39(4): 416-428.

Escobar, Arturo. 1994. Encountering Development. The Making and Unmaking of the Third World. Princeton: Princeton University Press.

Escobar, Arturo. 1999. The Invention of Development. Current History 98(631): 382-386.

European Commission. 2008. A Strategic European Framework for International Science and Technology Cooperation. Communication from the Commission to the Council and the European Parliament. Brussels, 24 September 2008 COM (2008) 588.

European Commission. 2012a. Enhancing and focusing EU international co-operation in research and innovation: A strategic approach. Communication from the Commission to the European Parliament, the Council, The European Economic and Social Committee and the Committee of the Regions. Brussels, 14.9.2012.

European Commission. 2012b. Overview of international science, technology and innovation cooperation between Member States and countries outside the EU and the development of a future monitoring mechanism. Final report for the specific contract 'INCO Monitoring' under the Framework Service Contract Nr -151364-2009 A08-BE. Luxembourg: Publications Office of the European Union.

European Commission. 2016. Report on the Implementation of the strategy for International Cooperation in Research \& Innovation, as annexed in the Impact Assessment of the Commission's Proposal for Horizon Europe. Progress Report 12018, Brussels, October 2016.

European Parliament. 2015. EU scientific cooperation with third countries. Brussels: European Parliamentary Research Service.

European Commission. 2018. Third Report on the Implementation of the Strategy for International Cooperation in Research and Innovation as annexed in the Impact Assessment of the Commission's Proposal for Horizon Europe.

Felt, Ulrike, Rayvon Fouché, Clark A. Miller, and Laurel Smith-Doerr. 2017. The Handbook of Science and Technology Studies. Cambridge MA: MIT Press.

Finnemore, Martha. 1993. International Organizations as Teachers of Norms: The United Nations Educational, Scientific, and Cultural Organization and Science Policy. International Organization 47(4): 565-597.

Fleury, Antoine, and Sacha Zala. 2012. Wissenschaft und Aussenpolitik. Einleitung. Quaderni di Dodis 1: 11-13. Bern 2012.

Freeman, Christopher, Raymond Poignant, and Ingvar Svennilson. 1965. Science, Economic Growth, and Government Policy. In Ministers Talk About Science. A Summary and Review of the First Ministerial Meeting on Science, eds. Emmanuel G. Mesthene, 95-119. Paris: OECD.

Freeman, Christopher. 1967. Science and Economy at the National Level. In: Problems in Science Policy, 60-65. OECD, Paris.

Freeman, Christopher. 1969. Measurement of Output of Research and Experimental Development. UNESCO Paper ST/S/16. 
Fuller, Steve, and James H. Collier. 2004 [1993]. Philosophy, Rhetoric, and the End of Knowledge. A New Beginning for Science and Technology Studies (2nd ed.). Mahwah, New Jersey: Lawrence Erlbaum Associates.

Garforth, Lisa, and Tereza Stöckelová. 2012. Science Policy and STS from Other Epistemic Places. Science, Technology, \& Human Values 37(2): 226-240.

Gibbons, Michael, Camille Limoges, Helga Nowotny, Simon Schwartzman, Peter Scott, and Martin Trow. 1994. The New Production of Knowledge: The Dynamics of Science and Research in Contemporary Societies. London: Sage.

Godin, Benoît. 2008. The Making of Statistical Standards: The OECD and the Frascati Manual, 1962-2002. Project on the History and Sociology of STI Statistics. Working Paper No. 39.

Godin, Benoît. 2009. The Making of Science, Technology and Innovation Policy: Conceptual Frameworks as Narratives, 1945-2005. Montréal: Centre - Urbanisation Culture Société de l'Institut national de la recherche scientifique.

Guston, David H. 1996. Principal-agent theory and the structure of science policy. Science and Public Policy 23: 229-240.

Guston, David H. 2000. Between Politics and Science: Assuring the Integrity and Productivity of Research. Cambridge: Cambridge University Press.

Hackett, Edward J., Olga Amsterdamska, Michael Lynch, and Judy Wajcman (eds.). 2007. The Handbook of Science and Technology Studies. Cambridge, Mass: MIT Press.

Hall, Stuart. 1992. The West and the Rest. Discourse and Power. In Formations of Modernity, eds. Stuart Hall and Bram Gieben, 275-320. Cambridge: The Open University Press.

Harding, Sandra. 2008. Sciences from Below: Feminisms, Postcolonialities, and Modernities. Durham, NC: Duke University Press.

Harding, Sandra. 2011. The Postcolonial Science and Technology Studies Reader. Durham, NC: Duke University Press.

Harries, Patrick. 2007. Butterflies \& Barbarians: Swiss Missionaries in South-East Africa. Oxford: James Currey.

Henriques, Luisa, and Philippe Larédo. 2013. Policy-making in science policy: the 'OECD model' unveiled. Research Policy 42(3): 801-816.

Hansen, Peo, and Stefan Jonsson. 2017. Eurafrica Incognita: The Colonial Origins of the European Union. History of the Present 7 (1): 1.

Hofmänner, Alexandra. 2018. New International Science \& Technology Policies: Key Issues and Questions in Switzerland. Bern: Swiss Science Council.

Jang, Yong Suk. 2000. The Worldwide Founding of Ministries of Science and Technology, 1950-1990. Sociological Perspectives 43(2): 247-270.

Jasanoff, Sheila. 1990. The Fifth Branch: Science Advisers as Policymakers. Cambridge, MA: Harvard University Press.

Jasanoff, Sheila. 2005. Designs on Nature: Science and Democracy in Europe and the United States. Princeton, NJ: Princeton University Press.

Keskinen, Suvi, Salla Tuori, Sara Irni, and Diana Mulinari. 2009. Complying with Colonialism: Gender, Race and Ethnicity in the Nordic Region. Aldershot: Ashgate.

King, Alexander. 1965. Science in the OECD. In Ministers Talk About Science. A Summary and Review of the First Ministerial Meeting on Science, October 1963, ed. Emmanuel G. Mesthene, 17-24. Paris: OECD.

Knauft, Bruce M. (ed.). 2002. Critically Modern? Alternatives, Alterities, Anthropologies. Bloomington: Indiana University Press.

Krige, John. 2006. American Hegemony and the Postwar Reconstruction in Europe. Cambridge, Mass.: MIT Press.

Law, John. 1987. Technology, closure and heterogeneous engineering: the case of the Portuguese expansion. In The Social Construction of Technological Systems, New Directions in the Sociology and History of Technology, eds. Wiebe E. Bijker, Thomas P. Hughes, and Trevor J. Pinch, 105-128. Cambridge, Mass: MIT Press.

Loftsdóttir, Kristin. 2012. Colonialism at the Margins: Politics of Difference in Europe as Seen Through Two Icelandic Crisis. Identities: Global Studies in Culture and Power 19(5): 597-615.

Lüthi, Barbara, Francesca Falk, and Patricia Purtschert. 2016. Colonialism without Colonies: Examining Blank Spaces in Colonial Studies. National Identities 18(1).

Macamo, Elisio. 2016. 'Before we start': science and power in the constitution of Africa. In The Politics of Nature and Science in Southern Africa, eds. Maano Ramutsindela, Giorgio Miescher, and Melanie Boehi, 323-334. Basel: Basler Afrika Bibliographien. 
Macamo, Elisio. 2018. Translating Black-Boxes - The social sciences and Africa. In Translation Revisited - Contesting the Sense of African Social Realities, eds. Diawara Ouédraogo and Elisio Macamo, 335-352. Cambridge: Cambridge Scholars Publishing.

Martin, Ben R. 2012. The evolution of science policy and innovation studies. Research Policy 41(7): 1219-1239.

McNeil, Maureen. 2005. Introduction: Postcolonial Technoscience. Science as Culture 14(2): 105-112.

Meier, Lukas. 2015. The Other's Colony: Switzerland and the Discovery of Côte d'Ivoire. In Colonial Switzerland: Rethinking Colonialism from the Margins. Basingstoke: Palgrave Macmillan.

Mesthene, Emmanuel G. 1965. Introduction. In Ministers Talk About Science. A Summary and Review of the First Ministerial Meeting on Science, October 1963, ed. Emmanuel G. Mesthene, 27-52. Paris: OECD.

Mitchell, Timothy. 2000a. Questions of Modernity. Minneapolis: University of Minnesota Press.

Mitchell, Timothy. 2000b. The Stage of Modernity. In Questions of Modernity, ed. Timothy Mitchell, 1-34. Minneapolis: University of Minnesota Press.

Mudimbe, Valentin Y. 1988. The Invention of Africa: Gnosis, Philosophy, and the Order of Knowledge. London: James Currey.

NATO. 1960. Increasing the Effectiveness of Western Science. Study Group of the NATO Science Committee.

Nowotny, H. 2007. How many policy rooms are there? Evidence-based and other kinds of science policies. Science, Technology, and Human Values 32(4): 479-490.

Nowotny, Helga, Peter Scott, and Michael Gibbons. 2001. Re-Thinking Science. Knowledge and the Public in an Age of Uncertainty. Cambridge: Polity Press.

OECD. 1962a. Science and the Policies of Governments: The Implications of Science and Technology for National and International Affairs. Report of the Secretary General's ad hoc Advisory Group on Science Policy. Paris: OECD.

OECD. 1962b. The Measurement of Scientific and Technical Activities: Proposed Standards Practice for Surveys of Research and Development (Frascati Manual). Paris: OECD.

OECD. 1965. Ministers Talk About Science. A Summary and Review of the First Ministerial Meeting on Science, October 1963. In Secretary of the Ministerial Meeting of Science, ed. Emmanuel G. Mesthene. Paris: OECD.

Osterhammel, Jürgen. 2010. Colonialism: A Theoretical Overview, 3rd ed. Princeton, NJ: University Press.

Ouédraogo, Jean-Bernard, Mamadou Diawara, and Elísio S. Macamo. 2018. Translation RevisitedContesting the Sense of African Social Realities. Cambridge: Cambridge Scholars Publishing.

Piganiol, P., K. Herz, R. Major, N.F. Ramsey, E.I. Schmidt, T.W. Schultz, and E.W.R. Steacie. 1963. Science and the policies of governments - The implications of science and technology for national and international affairs. Paris: OECD.

Porter, Tony, and Michael Webb. 2008. The role of the OECD in the orchestration of global knowledge networks. In The OECD and Transnational Governance, eds. Rianne Mahon and Stephen McBride, 43-59. Vancouver: UBC Press.

Prasad, Amit. 2008. Science in motion: what postcolonial science studies can offer. Elect. J. Commun. Inf. Innov. Health 2(2): 5-47.

Pratt, Mary Louise. 1992. Imperial Eyes. Studies in Travel Writing and Transculturation. London: Routledge.

Purtschert, Patricia, and Harald Fischer-Tiné. 2015. Colonial Switzerland: Rethinking Colonialism from the Margins. Cambridge Imperial and Post-colonial Studies Series. Basingstoke: Palgrave Macmillan.

Ramutsindela, Maano, Giorgio Miescher, and Melanie Boehi. 2016. The Politics of Nature and Science in Southern Africa. Basel: Basler Afrika Bibliographien.

Randeria, Shalini. 1999a. Geteilte Geschichte und verwobene Moderne. In Zukunftsentwürfe. Ideen für eine Kultur der Veränderung, eds. Jörn Rüsen, Hanna Leitgeb, Norbert Jegelka, and Chingiz Aĭtmatov, 87-96. Frankfurt a.M.: Campus.

Randeria, Shalini. 1999b. Jenseits von Soziologie und soziokultureller Anthropologie. Zur Ortsbestimmung der nichtwestlichen Welt in einer zukünftigen Sozialtheorie. Soziale Welt 50(4): 373-382.

Randeria, Shalini. 2002. Entangled Histories of Uneven Modernities. Civil Society, Caste Solidarities and the Post-Colonial State in India. In Unraveling Ties: From Social Cohesion to New Practices of Connectedness, eds. Yehuda Elkana, Ivan Krastev, Elisio Macamo, and Shalini Randeria, 284-311. Frankfurt a.M./New York: Campus/St. Martin's Press. 
Rip, Arie. 1994. The Republic of Science in the 1990s. Higher Education 28: 3-23.

Ronayne, Jarlath. 1984. Science in Government. A Review of the Principles and Practice of Science Policy. Baltimore: Arnold.

Rostow, Walt Whitman. 1959. The Stages of Economic Growth. The Economic History Review New Series 12(1): 1-16.

Said, Edward W. 2003 [1977]. Orientalism. Western Conceptions of the Orient. London: Penguin.

Salomon, Jean-Jacques. 1965. International Scientific Organizations. In Ministers Talk About Science. A Summary and Review of the First Ministerial Meeting on Science, October 1963, ed. Emmanuel G. Mesthene, 57-87. Paris: OECD.

Salomon, Jean-Jacques. 1973. Science and Politics. Cambridge, Mass: MIT Press.

Salomon, Jean-Jacques. 1977. Science policy studies and the development of science policy. In Science, Technology and Society, eds. Ina Spiegel-Rösing and Derek de Solla Price, 43-70. London: Sage.

Schlegel, Flavia. 2014. Swiss Science Diplomacy: Harnessing the Inventiveness and Excellence of the Private and Public Sectors. Science \& Diplomacy 3(1).

SER. 2010. Switzerland's International Strategy for Education, Research and Innovation. Approved by the Federal Council on 30 June 2010. Bern: State Secretariat for Education and Research (SER).

Seth, Suman. 2009. Putting knowledge in its place: Science, colonialism, and the postcolonial. Postcolonial Studies 12(4): 373-388.

Sismondo, Sergio. 2008. Science and Technology Studies and an Engaged Program. In The Handbook of Science and Technology Studies, eds. Edward J. Hackett, Olga Amsterdamska, Michael Lynch, and Judy Wajcman, 13-17. Cambridge and London: MIT Press.

Spaey, Jacques. 1971. Science for Development: An Essay on the Origin and Organization of National Science Policies. Paris: UNESCO.

Spiegel-Rösing, Ina, and Derek de Solla Price (eds.).1977. Science, Technology and Society: A CrossDisciplinary Perspective. London: Sage.

Spivak, Gayatri Chakravorty. 1988. Can the Subaltern Speak? In Marxism and the Interpretation of Culture, eds. Cary Nelson and Lawrence Grossberg, 271-316. Urbana/Chicago: University of Illinois Press.

Swiss Science and Technology Council. 2009. Empfehlungen des SWTR zur Wissenschaftsaussenpolitik. SWTR Schrift 5/2009. Bern: Schweizerischer Wissenschafts- und Technologierat.

Trouillot, Michel-Rolph. 1991. Anthropology and the Savage Slot: The Poetics and Politics of Otherness. In Recapturing Anthropology: Working in the Present, ed. Richard G. Fox, 17-44. Santa Fe, N.M.: School of American Research Press.

Trouillot, Michel-Rolph. 2002. The Otherwise Modern. Caribbean Lessons from the Savage Slot. In Critically Modern? Alternatives, Alterities, Anthropologies, ed. Bruce M. Knauft, 220-237. Bloomington: Indiana University Press.

Trouillot, Michel-Rolph. 2003. Global Transformations: Anthropology and the Modern World. New York: Palgrave Macmillan.

United Nations. 1963. Science and Technology for Development. Report on the United Nations Conference on the Application of Science and Technology for the Benefit of the Less Developed Areas, Geneva, 4-21 February 1963 (UNCSAT). United Nations; New York.

Van der Meulen, Barend. 1998. Science Policies as Principal-Agent Games. Institutionalization and Path Dependency in the Relation between Government and Science. Research Policy 27: 397-411.

Webster, Andrew. 2007. Crossing Boundaries: STS in the Policy Room. Science, Technology, \& Human Values 32: 458-478.

Weingart, Peter. 1999. Scientific expertise and political accountability: paradoxes of science in politics. Science and Public Policy 26(3): 151-161.

Weingart, Peter. 2001. Die Stunde der Wahrheit? Zum Verhältnis der Wissenschaft zu Politik, Wirtschaft und Medien in der Wissensgesellschaft. Weilerswist: Velbrück Verlag.

Wilgress, Dana. 1960. Cooperation in Scientific and Technical Research (Wilgress Report). Paris: OEEC. Wynne, Brian. 2007. Dazzled by the Mirage of Influence? Science, Technology, \& Human Values 32: 491-503.

Publisher's Note Springer Nature remains neutral with regard to jurisdictional claims in published maps and institutional affiliations. 